\title{
Kajian Perilaku Struktur Portal Beton Bertulang Tipe SRPMK dan Tipe SRPMM
}

\author{
Nur Laeli Hajati dan Rizki Noviansyah \\ Jurusan Teknik Sipil, Institut Teknologi Nasional (Itenas) Bandung \\ Email: eli10871@gmail.com
}

\begin{abstract}
Moment Resisting Frame System (SRPM) is one of the earthquake resistant structural systems that is often used in Indonesia. SRPM is classified into three types are Ordinary Moment Resisting Frame System (SRPMB), Intermediate Moment Resisting Frame System (SRPMM), and Special Moment Resisting Frame System (SRPMK). In this final project, the structure of the building is modeled with SRPMM and SRPMK in areas with high seismicity (Seismic Design Category D) in the city of Yogyakarta, then compared the behavior of the structure between the two models. The result of this research is SRPMM which its purpose for medium earthquake area, can still give good performance which is indicated by fulfillment of design requirement, performance when performance point is in Immadiate Occupancy condition up to Life Safe, and give good ductility value when Collapse occurred.
\end{abstract}

Keywords: intermediate moment resisting frame system, special moment resisting frame system, performance point, ductility

\begin{abstract}
ABSTRAK
Sistem Rangka Pemikul Momen (SRPM) adalah salah satu sistem struktur penahan gempa yang sering digunakan di Indonesia. SRPM dibagi menjadi tiga jenis yaitu Sistem Rangka Pemikul Momen Biasa (SRPMB), Sistem Rangka Pemikul Momen Menengah (SRPMM), dan Sistem Rangka Pemikul Momen Khusus (SRPMK). Dalam tugas akhir ini struktur gedung dimodelkan dengan SRPMM dan SRPMK pada wilayah dengan tingkat kegempaan tinggi (Kategori Desain Seismik D) dikota Yogyakarta, kemudian dibandingkan perilaku struktur antara kedua model tersebut. Hasil dari penelitian ini adalah SRPMM yang peruntukannya untuk wilayah gempa sedang, tetap dapat memberikan kinerja cukup baik yang ditunjukkan dengan terpenuhinya persyaratan-persyaratan desain, kinerja pada saat performance point berada pada kondisi Immadiate Occupancy sampai dengan Life Safe, serta memberikan nilai daktilitas yang baik ketika terjadi keruntuhan.
\end{abstract}

Kata kunci: SRPMM, SRPMK, performance point, daktilitas. 


\section{PENDAHULUAN}

Desain struktur bangunan untuk wilayah rentan gempa harus direncanakan mencakup untuk kondisi tahan gempa. Model struktur didesain sesuai dengan SNI 1726-2012 tentang Tata Cara Perencanaan Ketahanan Gempa untuk Struktur Bangunan Gedung dan Non Gedung ([3]).

Model struktur dievaluasi dalam 2 (dua) tahap, yaitu:

1. Tahap ke-1: analisis secara dinamik halmana struktur dibebani beban mati (DL), beban mati tambahan (SDL), beban hidup (LL), beban angin (W), dan beban gempa (EQ).

Untuk beban gempa dibuat berdasarkan kurva respon spektrum sesuai kondisi tanah struktur.

Output yang diperoleh dari tahap ke-1 adalah perioda (waktu getar struktur) dalam beberapa mode awal, nilai gaya dalam struktur.

2. Tahap ke-2: analisis secara statik dengan Metode Performance Based Seismic Design (PBSD), halmana metode evaluasi menggunakan Metode Static Linear Pushover Analysis untuk memperoleh gambaran tahapan perilaku struktur dan taraf kinerja struktur sampai kondisi kritis akibat beban gempa yang dimodelkan.

Output yang diperoleh dari Tahap ke-2 adalah kurva capacity dan kurva demand, halmana gabungan dari kedua kurva tersebut menghasilkan performance point dari struktur.

Penelitian ini bertujuan membandingkan kinerja struktur gedung bermaterial beton bertulang antara model Sistem Rangka Pemikul Momen Khusus (SRPMK) dan Sistem Rangka Pemikul Momen Menengah (SRPMM) pada tingkat resiko kegempaan tinggi.

\section{METODOLOGI}

Pada penelitian ini, struktur bangunan direncanakan dengan material beton bertulang pada tingkat resiko kegempaan tinggi [3] berupa model Sistem Rangka Pemikul Momen Khusus (SRPMK) dengan nilai $R$ (Koefisien Modifikasi Respon) sebesar 5 dan Sistem Rangka Pemikul Momen Khusus (SRPMK) nilai $R$ (Koefisien Modifikasi Respon) sebesar 8.

\subsection{Tahapan Keruntuhan dan Tingkat Kinerja Struktur}

Tahapan keruntuhan struktur dan tingkat kinerja struktur dapat diprediksi dengan mengaplikasikan Metode Performance Based Seismic Design (PBSD) dalam analisis struktur. Performance objectives (sasaran kinerja) yang merupakan tingkat kinerja bangunan yang diharapkan pada saat dikenai beban gempa tertentu digambarkan pada Tabel 1. Performance objectives struktur terdiri atas 2 (dua) elemen pokok, yaitu hazard levels dan performance levels.

Tabel 1: Basic Safety Performance [1]

\begin{tabular}{|c|c|c|c|c|}
\hline \multirow[b]{2}{*}{ EQ Ground Motion } & \multicolumn{4}{|c|}{ Building Performance Level } \\
\hline & Operational & $\begin{array}{l}\text { Immediate } \\
\text { Occupancy }\end{array}$ & $\begin{array}{c}\text { Life } \\
\text { Safety }\end{array}$ & $\begin{array}{c}\text { Structural } \\
\text { Stability }\end{array}$ \\
\hline \multicolumn{5}{|l|}{ Serviceability EQ (SE) } \\
\hline Design $E Q(D E)$ & & & $\checkmark$ & \\
\hline Maximum EQ (ME) & & & & $\checkmark$ \\
\hline
\end{tabular}

\section{Catatan:}

Serviceability $E Q(S E)$ adalah gempa dengan probabilitas terlampauinya percepatan tanah maksimum dalam rentang masa layan 50 tahun adalah $50 \%$,

Design $E Q(D E)$ adalah gempa dengan probabilitas terlampauinya percepatan tanah maksimum dalam rentang masa layan 50 tahun adalah $10 \%$,

Maximum EQ $(M E)$ adalah gempa dengan probabilitas terlampauinya percepatan tanah maksimum dalam rentang masa layan 50 tahun adalah $5 \%$. 
Hazard levels adalah level-level ancaman gerakan tanah akibat gempa yang didasarkan atas percent risk (\% risk) atau persen resiko yang boleh dilampaui selama masa layan bangunan.

Performance levels (tingkat kinerja) adalah serangkaian level-kinerja struktur atas akibat tiap-tiap tingkatan hazard levels yang membatasi kondisi struktur berdasarkan kerusakan fisik struktur, keselamatan jiwa di dalamnya, kemampuan layan struktur pasca gempa, tingkat kinerja bangunan (building performance level) meliputi elemen struktural dan non-struktural.

ATC-40 dan FEMA-237 [5] telah mengembangkan model prosedur performance levels, acceptance criteria, dan push-over analysis. Dalam dukumen ATC-40 dijelaskan definisi hubungan antara deformasi (deformation) dan gaya (force) pada tahapan pembentukan sendi plastis melalui push-over analysis.

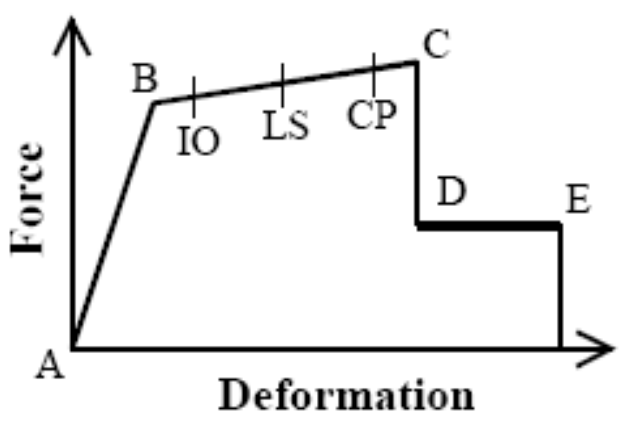

Gambar 1. Kurva Deformasi terhadap Gaya pada sendi plastis melalui push-over analysis [1] dan [8]

Pada Gambar 1 diilustrasikan tahapan-tahapan kreiteria hubungan deformasi terhadap gaya pada sendi plastis melalui push-over analysis. Elemen berada pada kondisi elastis hingga leleh pertama pada titik $B$, kemudian mengalami strain hardening sampai titik $C$, selanjutnya pada fase $D E$ elemen struktur mengalami penurunan kekuatan dan hanya sanggup menahan beban gravitasi hingga runtuh total (final collapse) pada titik E. Secara garis besar terdapat 4 kriteria dalam Performance Level [7], sbb.:

- Operational, merupakan suatu tahap halmana dapat diindikasikan tidak ada kerusakan struktural maupun nonstruktural yang berarti pada struktur, struktur masih dapat berfungsi dengan baik,

- Immediate Occupancy (IO), merupakan suatu tahap halmana dapat diindikasikan tidak ada kerusakan yang berati pada struktur, kekuatan dan kekakuan struktur kira-kira sama dengan kondisi sebelum terjadi beban gempa. Komponen non-struktural masih berada pada tempatnya dan sebagian besar masih berfungsi jika utilitasnya tersedia. Bangunan tetap dapat berfungsi tanpa terganggu masalah perbaikan.

- Life Safety (LS),

merupakan suatu tahap halmana dapat diindikasikan telah terjadi kerusakan pada elemen struktural tetapi masih bersifat daktail. Komponen non-struktural masih ada tetapi sudah tidak berfungsi, bangunan masih dapat digunakan setelah dilakukan perbaikan.

- Collapse Prevention (CP), merupakan suatu tahap halmana dapat diindikasikan telah terjadi kerusakan pada elemen struktural dan non-struktural, bangunan hampir runtuh dan sudah tidak dapat dipakai.

\subsection{Aspek Kinerja Struktur}

Analisis model struktur dilakukan dalam 2 (dua tahap), yaitu: analisis struktur pada tahap ke-1 berupa analisis secara dinamik halmana struktur dibebani beban mati (DL), beban mati tambahan (SDL), beban hidup (LL), beban angin (W), dan beban gempa (EQ), halmana beban gempa berada pada tingkat resiko kegempaan tinggi; analisis struktur pada tahap ke-2 berupa analisis secara statik 
halmana struktur dibebani secara statik dengan Metode Linear Pushover Analysis. Selanjutnya kedua model struktur ini (SRPMM dan SRPMK) dibandingkan kinerja strukturnya, meliputi aspek perioda, gaya geser dasar, simpangan antar lantai, dan nilai daktilitas.

Analisis beban dorong statik (static push-over analysis) adalah suatu cara analisis statik 2 dimensi atau 3 dimensi linier dan non-linier, halmana pengaruh gempa rencana terhadap struktur dianggap sebagai beban statik yang menangkap pada pusat massa masing-masing lantai, yang nilainya ditingkatkan secara berangsur-angsur sampai melalui pembebanan yang menyebabkan pelelehan (sendi plastis) pertama di dalam struktur gedung, kemudian dengan peningkatan beban lebih lanjut mengalami perubahan bentuk elasto-plastis yang besar sampai mencapai kondisi diambang keruntuhan.

Untuk mengetahui batas kinerja struktur dapat diketahui dengan menggunakan Metode Spektrum Kapasitas (CSM). Pada metode ini spektrum respon percepatan dan kurva kapasitas diplot dalam satu format spektrum yang disebut Acceleration Displacement Respon Spectra (ADRS), seperti yang digambarkan bentuk umumnya pada Gambar 2.

Terdapat 3 (tiga) elemen pada kurva ADRS, sbb.:

1. Demand spectrum merepresentasikan gerakan tanah saat terjadi gempa,

2. Capacity spectrum (kurva push-over) merepresentasikan kemampuan struktur menahan demand akibat gempa,

3. Performance point yang merupakan titik pertemuan demand spectrum dengan capacity spectrum digunakan untuk memeriksa apakah komponen struktural dan non-struktural tidak melebihi batas kerusakan yang telah ditetapkan pada performance objective.



Gambar 2. Kurva Acceleration Displacement Respon Spectra (ADRS) [1] dan [8]

Daktilitas adalah kemampuan struktur atau komponennya untuk melakukan deformasi inelastis besar secara bolak-balik dan berulang yang menyebabkan terjadinya pelelehan pertama sambil mempertahankan kekuatan dan kekakuan yang cukup, sehingga struktur tersebut tetap berdiri walaupun sudah berada dalam kondisi diambang keruntuhan [6].

Menurut SNI 1726-2002 tentang Standar Perencanaan Ketahanan Gempa untuk Struktur Bangunan Gedung ([2]), faktor daktilitas struktur $\mu$ gedung didefinisikan sebagai rasio antara simpangan maksimum struktur gedung akibat pengaruh gempa rencana pada saat mencapai kondisi di ambang keruntuhan $\delta_{m}$ dan simpangan struktur gedung pada saat terjadinya pelelehan pertama $\delta_{y}$, yaitu:

$$
1,0 \leq \mu=\frac{\delta_{m}}{\delta_{y}} \leq \mu_{m}
$$


halmana:

$\mu=1,0$ adalah nilai faktor daktilitas untuk struktur gedung berperilaku elastik penuh,

$\mu_{m}$ adalah nilai faktor daktilitas maksimum yang dapat dikerahkan oleh sistem gedung yang bersangkutan.

Garis besar langkah-langkah penelitian disajikan dalam Gambar 3 berikut:

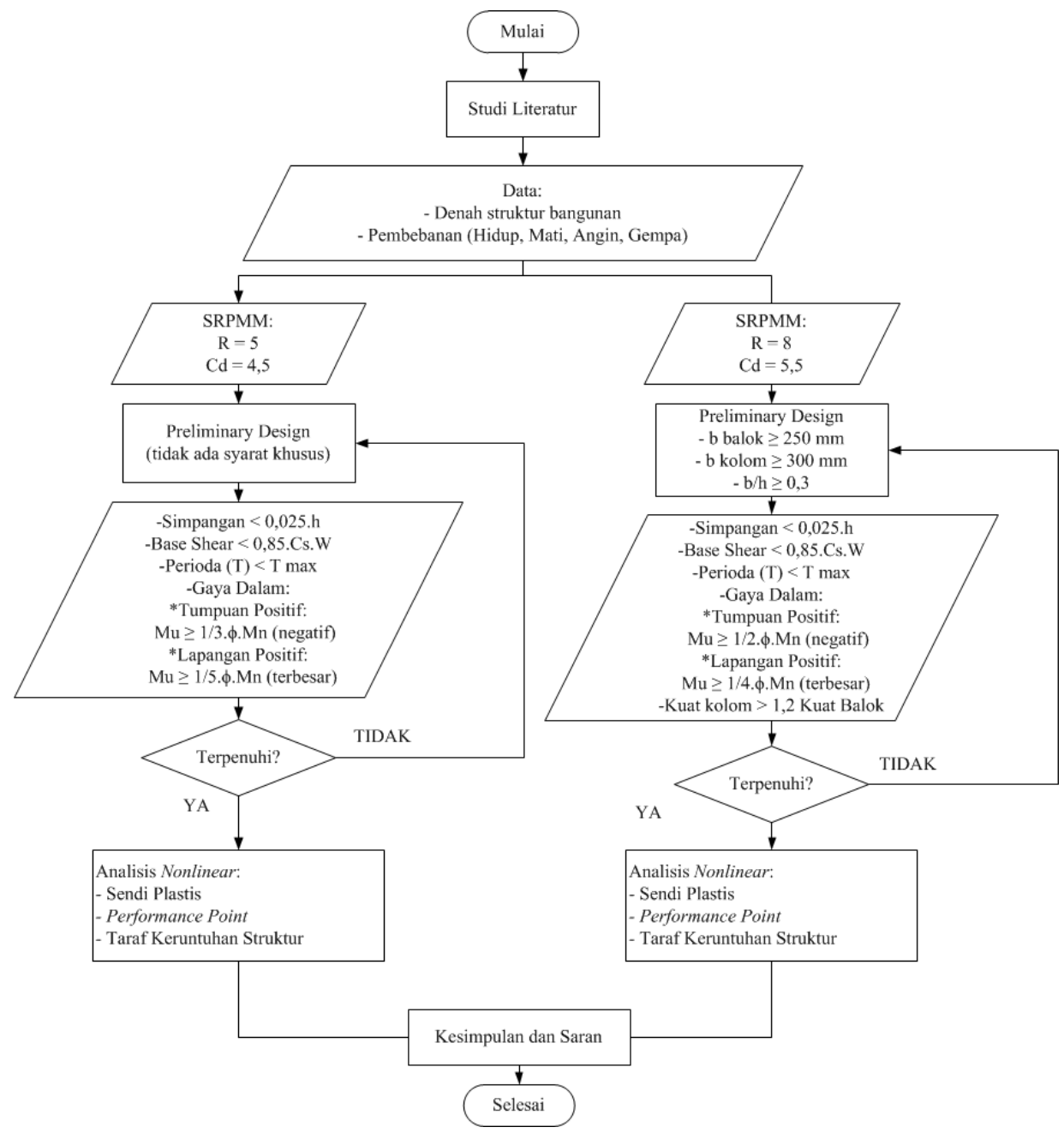

Gambar 3. Bagan alir penelitian berdasarkan [4]

\section{DESAIN DAN PEMODELAN}

Model yang dibuat adalah struktur portal beton bertulang dengan dua tipe yaitu tipe Sistem Rangka Pemikul Momen Khusus (SRPMK) dan tipe Sistem Rangka Pemikul Momen Menengah (SRPMM) yang keduanya diberikan beban gempa yang termasuk kedalam resiko kegempaan tinggi (KDS D = Kategori Desian Seismik D).

Adapun data-data struktur bangunan yang dikaji adalah sebagai berikut:

1. Bangunan gedung 10 lantai.

2. Fungsi gedung untuk rumah susun.

3. Wilayah kegempaan resiko tinggi (KDS D = Kategori Desain Seismik D) di Kota Yogyakarta. 


\subsection{Hasil Desain}

Denah struktur bangunan seperti pada Gambar $\mathbf{4}$ berikut:

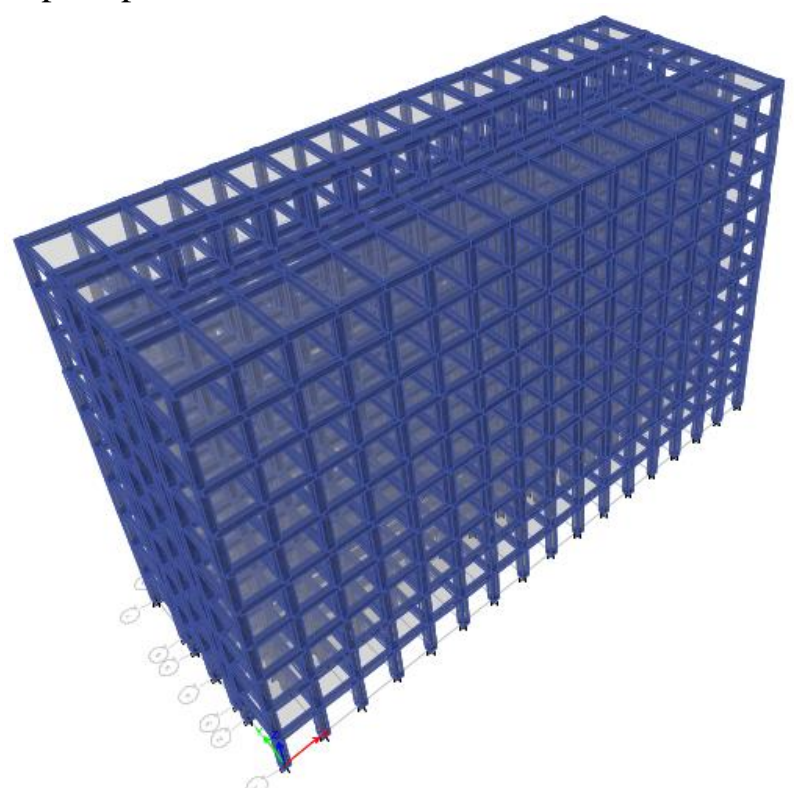

Gambar 4. Denah struktur bangunan

Struktur bangunan bersifat tipikal untuk setiap lantainya dan mempunyai tinggi tiap lantai 4 meter. Struktur bangunan tipe ke-1 direncanakan dengan konsep SRPMK dan tipe ke-2 direncanakan dengan konsep SRPMM, dengan dimensi dan konfigurasi baja tulangan disajikan pada Tabel 2, Tabel 3, Tabel 4, dan Tabel 5 sebagai berikut:

Tabel 2. Konfigurasi baja tulangan balok SRPMK

\begin{tabular}{rrrrrrrrr}
\hline \multicolumn{1}{c}{ Tipe } & \multicolumn{2}{c}{ Dimensi } & \multicolumn{2}{c}{ Tumpuan } & \multicolumn{2}{c}{ Lapangan } & \multicolumn{2}{c}{ Sengkang } \\
Balok & $\boldsymbol{b}[\mathbf{m m}]$ & $\boldsymbol{h}[\mathbf{m m}]$ & Atas & Bawah & Atas & Bawah & Tumpuan & Lapangan \\
\hline B1 & 300 & 500 & 5D22 & 3D22 & 2D22 & 2D2 & 2D13 - 100 & 2D13 - 200 \\
\hline B2 & 300 & 500 & 7D22 & 5D22 & 2D22 & 3D2 & 3D13 - 100 & 2D13 - 200 \\
\hline B3 & 300 & 500 & 7D22 & 5D22 & 2D22 & 2D2 & 3D13 - 100 & 3D13 - 100 \\
\hline B4 & 300 & 500 & 7D22 & 5D22 & 2D22 & 2D & 3D13 - 100 & 2D13 - 200 \\
\hline
\end{tabular}

Tabel 3. Konfigurasi baja tulangan balok SRPMM

\begin{tabular}{ccccccccc}
\hline Tipe & \multicolumn{2}{c}{ Dimensi } & \multicolumn{2}{c}{ Tumpuan } & \multicolumn{2}{c}{ Lapangan } & \multicolumn{2}{c}{ Sengkang } \\
Balok & $\boldsymbol{b}[\mathbf{m m}]$ & $\boldsymbol{h}[\mathbf{m m}]$ & Atas & Bawah & Atas & Bawah & Tumpuan & Lapangan \\
\hline $\mathrm{B} 1$ & 400 & 650 & 8D22 & 6D22 & 2D22 & 3D22 & 2D10-125 & 2D10 - 175 \\
\hline $\mathrm{B} 2$ & 400 & 650 & 10D22 & 6D22 & 2D22 & 3D22 & 4D10-125 & 2D10 - 200 \\
\hline $\mathrm{B} 3$ & 400 & 650 & 10D22 & 8D22 & 2D22 & 3D22 & 4D10- 125 & 4D10 - 125 \\
\hline $\mathrm{B} 4$ & 400 & 650 & 10D22 & 8D22 & 2D22 & 3D22 & 4D10 - 125 & 2D10 - 200 \\
\hline
\end{tabular}


Tabel 4. Konfigurasi baja tulangan kolom SRPMK

\begin{tabular}{ccccccc}
\hline \multirow{2}{*}{ Lantai } & Tipe & \multicolumn{2}{c}{ Dimensi } & Tulangan & \multicolumn{2}{c}{ Sengkang } \\
& Kolom & $\boldsymbol{b}[\mathbf{m m}]$ & $\boldsymbol{h}[\mathbf{m m}]$ & & Bentang $\boldsymbol{l}_{\mathbf{0}}$ & Luar $\boldsymbol{l}_{\mathbf{0}}$ \\
\hline Base - Lantai 2 & $\mathrm{K} 1$ & 550 & 550 & 20D22 & 3D13 - 100 & 2D13 - 150 \\
\hline Lantai 3 - Lantai 6 & K2 & 550 & 550 & 16D22 & 3D13 - 100 & 2D13 - 150 \\
\hline Lantai 7 - Lantai 9 & K3 & 450 & 450 & 16D22 & 3D13 - 100 & 2D13 - 150 \\
\hline
\end{tabular}

Tabel 5. Konfigurasi baja tulangan kolom SRPMM

\begin{tabular}{ccccccc}
\hline \multirow{2}{*}{ Lantai } & Tipe & \multicolumn{2}{c}{ Dimensi } & Tulangan & \multicolumn{2}{c}{ Sengkang } \\
& Kolom & $\boldsymbol{b}[\mathbf{m m}]$ & $\boldsymbol{h}[\mathbf{m m}]$ & & Bentang $\boldsymbol{l}_{\mathbf{0}}$ & Luar $\boldsymbol{l}_{\mathbf{0}}$ \\
\hline Base - Lantai 2 & $\mathrm{K} 1$ & 650 & 650 & 28D22 & 2D13 - 150 & 2D13 - 200 \\
\hline Lantai 3 - Lantai 6 & $\mathrm{K} 2$ & 650 & 650 & 16D22 & 2D13 - 150 & 2D13 - 200 \\
\hline Lantai 7 - Lantai 9 & K3 & 550 & 550 & 16D22 & 2D13 - 150 & 2D13 - 200 \\
\hline
\end{tabular}

\section{HASIL ANALISIS DAN PEMBAHASAN}

Hasil penelitian menunjukkan karakter dan kinerja struktur SRPMK berbeda dengan karakter dan kinerja struktur SRPMM, seperti yang diuraikan dalam 3 (tiga) parameter berikut: perioda struktur, gaya geser dasar, simpangan antar lantai; serta 2 (dua) aspek berikut: tahap keruntuhan struktur dan kinerja struktur.

\subsection{Perioda Struktur}

Pada Tabel 6 berikut ditunjukkan nilai perioda struktur kedua tipe struktur.

Tabel 6. Perioda struktur SRPMK dan SRPMM

\begin{tabular}{cccl}
\hline Mode & $\begin{array}{c}\text { SRPMK } \\
\text { Perioda [detik] }\end{array}$ & $\begin{array}{c}\text { SRPMM } \\
\text { Perioda [detik] }\end{array}$ & \multicolumn{1}{c}{ Keterangan } \\
\hline 1 & 1,793 & 1,302 & First Mode B-T \\
\hline 2 & 1,598 & 1,143 & First Mode Torsion \\
\hline 3 & 1,470 & 1,036 & First Mode $U$ - $S$ \\
\hline 4 & 0,580 & 0,422 & Second Mode $B-T$ \\
\hline 5 & 0,535 & 0,384 & Second Mode Torsion \\
\hline 6 & 0,506 & 0,358 & Second Mode $U-S$ \\
\hline 7 & 0,318 & 0,232 & Third Mode B-T \\
\hline 8 & 0,303 & 0,219 & Third Mode Torsion \\
\hline 9 & 0,296 & 0,211 & Third Mode $U$ - $S$ \\
\hline 10 & 0,212 & 0,156 & Fourth Mode $U$-S \\
\hline 11 & 0,203 & 0,149 & Fourth Mode Torsion \\
\hline 12 & 0,200 & 0,145 & Fourth Mode $B$ - $T$ \\
\hline
\end{tabular}

Berdasarkan Tabel 6 di atas diketahui bahwa nilai perioda struktur untuk tipe SRPMM lebih kecil daripada nilai perioda SRPMK, hal ini diduga karena pada SRPMM dimensi penampang melintang elemen struktur lebih besar, sehingga gaya dalam yang bekerja pada SRPMM menjadi lebih besar dan hal ini berdampak menyebabkan struktur SRPMM lebih kaku. 


\subsection{Gaya Geser Dasar}

Pada Tabel 7 berikut ditunjukkan nilai gaya geser dasar kedua tipe struktur.

Tabel 7. Gaya Geser Dasar SRPMK dan SRPMM

\begin{tabular}{cccc}
\hline \multirow{2}{*}{ Tipe } & $\begin{array}{c}\text { Load } \\
\text { Case/Combo }\end{array}$ & $\begin{array}{c}\text { FX } \\
{[\mathbf{k N}]}\end{array}$ & $\begin{array}{c}\text { FX } \\
{[\mathbf{k N}]}\end{array}$ \\
\hline \multirow{2}{*}{ SRPMK } & ENVELOPE Max & $7.372,875$ & $6.795,343$ \\
\cline { 2 - 4 } & ENVELOPE Min & $-7.372,875$ & $-6.795,343$ \\
\hline \multirow{2}{*}{ SRPMM } & ENVELOPE Max & $19.981,539$ & $15.889,079$ \\
\cline { 2 - 4 } & ENVELOPE Min & $-19.981,539$ & $-15.889,079$ \\
\hline
\end{tabular}

Berdasarkan Tabel 7 di atas diketahui bahwa nilai gaya geser terbesar adalah pada tipe struktur SRPMM, hal ini karena struktur SRPMM mempunyai dimensi yang lebih besar dari struktur SRPMK sehingga struktur SRPMM dapat memikul gaya geser yang lebih besar daripada SRPMK.

\subsection{Simpangan Antar Lantai}

Pada Tabel 8 berikut ditunjukkan nilai simpangan antar lantai kedua tipe struktur.

Tabel 8. Simpangan antar lantai SRPMK dan SRPMM

\begin{tabular}{|c|c|c|c|c|c|}
\hline \multirow[b]{2}{*}{ Lantai } & \multicolumn{2}{|c|}{ SRPMK } & \multicolumn{2}{|c|}{ SRPMM } & \multirow{2}{*}{$\begin{array}{c}\text { Simpangan } \\
\text { Izin [mm] }\end{array}$} \\
\hline & $\begin{array}{c}\operatorname{Arah} X \\
{[\mathbf{m m}]}\end{array}$ & $\begin{array}{c}\text { Arah } Y \\
{[\mathrm{~mm}]}\end{array}$ & $\begin{array}{c}\operatorname{Arah} X \\
{[\mathrm{~mm}]}\end{array}$ & $\begin{array}{c}\text { Arah } Y \\
{[\mathrm{~mm}]}\end{array}$ & \\
\hline Atap & 7,70 & 23,10 & 5,85 & 16,65 & 100 \\
\hline 9 & 17,60 & 34,10 & 11,25 & 22,50 & 100 \\
\hline 8 & 26,40 & 44,00 & 16,20 & 27,45 & 100 \\
\hline 7 & 25,85 & 44,00 & 20,70 & 32,40 & 100 \\
\hline 6 & 29,70 & 47,30 & 24,75 & 36,00 & 100 \\
\hline 5 & 33,55 & 50,60 & 27,45 & 37,80 & 100 \\
\hline 4 & 35,75 & 50,60 & 29,70 & 38,70 & 100 \\
\hline 3 & 37,40 & 49,50 & 31,05 & 37,80 & 100 \\
\hline 2 & 36,30 & 44,00 & 30,60 & 34,20 & 100 \\
\hline 1 & 22,55 & 24,75 & 22,05 & 21,60 & 100 \\
\hline
\end{tabular}

Berdasarkan Tabel 8 di atas diketahui bahwa nilai simpangan antar lantai tipe SRPMK lebih besar daripada SRPMM, hal ini disebabkan SRPMM lebih kaku daripada SRPMK yang ditunjukkan dengan nilai perioda yang lebih kecil, karena perioda struktur berbanding terbalik dengan kekakuan struktur, serta beban gempa yang dipikul SRPMM lebih kecil daripada beban gempa yang dipikul SRPMK.

\subsection{Keruntuhan Struktur}

Tahap keruntuhan berdasarkan distribusi sendi plastis untuk struktur SRPMK pada arah $X$ dan arah $Y$ ditampilkan pada Tabel 9 dan Tabel 10 sedangkan untuk struktur SRPMM pada arah $X$ dan arah $Y$ ditampilkan pada Tabel 11 dan Tabel 12.

Tabel 9. Distribusi sendi plastis struktur SRPMK arah $X$

\begin{tabular}{cccccccccccc}
\hline Step & $\begin{array}{c}\text { Disp. } \\
{[\mathbf{m m}]}\end{array}$ & $\begin{array}{c}\text { BaseForce } \\
{[\mathbf{k N}]}\end{array}$ & AtoB & BtoIO & IOtoLS & LStoCP & CPtoC & CtoD & DtoE & $>$ E & Total \\
\hline 0 & 0 & 0 & 6.280 & 0 & 0 & 0 & 0 & 0 & 0 & 0 & 6.280 \\
\hline 1 & 57 & 14.273 & 6.273 & 7 & 0 & 0 & 0 & 0 & 0 & 0 & 6.280 \\
\hline 2 & 127 & 26.210 & 5.426 & 428 & 426 & 0 & 0 & 0 & 0 & 0 & 6.280 \\
\hline 3 & 291 & 37.564 & 4.567 & 392 & 489 & 74 & 758 & 0 & 0 & 0 & 6.280 \\
\hline 4 & 455 & 45.056 & 4.151 & 155 & 754 & 166 & 1.054 & 0 & 0 & 0 & 6.280 \\
\hline
\end{tabular}




\begin{tabular}{cccccccccccc}
\hline Step & $\begin{array}{c}\text { Disp. } \\
{[\mathbf{m m}]}\end{array}$ & $\begin{array}{c}\text { BaseForce } \\
{[\mathbf{k N}]}\end{array}$ & AtoB & BtoIO & IOtoLS & LStoCP & CPtoC & CtoD & DtoE & $>$ E Total \\
\hline 5 & 617 & 49.915 & 3.735 & 349 & 473 & 162 & 1.561 & 0 & 0 & 0 & 6.280 \\
\hline 6 & 628 & 50.146 & 3.700 & 369 & 466 & 171 & 1.574 & 0 & 0 & 0 & 6.280 \\
\hline
\end{tabular}

Tabel 10. Distribusi sendi plastis struktur SRPMK arah Y

\begin{tabular}{cccccccccccc}
\hline Step & $\begin{array}{c}\text { Disp. } \\
{[\mathrm{mm}]}\end{array}$ & $\begin{array}{c}\text { BaseForce } \\
{[\mathrm{kN}]}\end{array}$ & AtoB & BtoIO & IOtoLS & LStoCP & CPtoC & CtoD & DtoE & $>$ E & Total \\
\hline 0 & 0 & 0 & 6.280 & 0 & 0 & 0 & 0 & 0 & 0 & 0 & 6.280 \\
\hline 1 & 76 & 20.037 & 6.267 & 13 & 0 & 0 & 0 & 0 & 0 & 0 & 6.280 \\
\hline 2 & 126 & 31.100 & 5.817 & 390 & 73 & 0 & 0 & 0 & 0 & 0 & 6.280 \\
\hline 3 & 179 & 37.065 & 5.351 & 360 & 514 & 29 & 26 & 0 & 0 & 0 & 6.280 \\
\hline 4 & 210 & 38.843 & 5.138 & 356 & 578 & 73 & 135 & 0 & 0 & 0 & 6.280 \\
\hline 5 & 330 & 42.270 & 4.711 & 394 & 550 & 140 & 485 & 0 & 0 & 0 & 6.280 \\
\hline 6 & 421 & 43.933 & 4.530 & 306 & 708 & 109 & 627 & 0 & 0 & 0 & 6.280 \\
\hline
\end{tabular}

Tabel 11. Distribusi sendi plastis struktur SRPMM arah $X$

\begin{tabular}{cccccccccccc}
\hline Step & $\begin{array}{c}\text { Disp. } \\
{[\mathbf{m m}]}\end{array}$ & $\begin{array}{c}\text { BaseForce } \\
{[\mathbf{k N}]}\end{array}$ & AtoB & BtoIO & IOtoLS & LStoCP & CPtoC & CtoD & DtoE & $>$ E & Total \\
\hline 0 & 0 & 0 & 6.280 & 0 & 0 & 0 & 0 & 0 & 0 & 0 & 6.280 \\
\hline 1 & 58 & 31.683 & 6.278 & 2 & 0 & 0 & 0 & 0 & 0 & 0 & 6.280 \\
\hline 2 & 85 & 42.546 & 5.788 & 492 & 0 & 0 & 0 & 0 & 0 & 0 & 6.280 \\
\hline 3 & 162 & 55.104 & 5.219 & 627 & 434 & 0 & 0 & 0 & 0 & 0 & 6.280 \\
\hline 4 & 324 & 66.749 & 4.727 & 557 & 891 & 34 & 71 & 0 & 0 & 0 & 6.280 \\
\hline 5 & 487 & 76.608 & 4.296 & 588 & 706 & 386 & 304 & 0 & 0 & 0 & 6.280 \\
\hline 6 & 533 & 78.950 & 4.072 & 740 & 742 & 215 & 511 & 0 & 0 & 0 & 6.280 \\
\hline 7 & 533 & 78.895 & 4.072 & 740 & 742 & 215 & 511 & 0 & 0 & 0 & 6.280 \\
\hline
\end{tabular}

Tabel 12. Distribusi sendi plastis struktur SRPMM arah $Y$

\begin{tabular}{cccccccccccc}
\hline Step & $\begin{array}{c}\text { Disp. } \\
{[\mathbf{m m}]}\end{array}$ & $\begin{array}{c}\text { BaseForce } \\
{[\mathbf{k N}]}\end{array}$ & AtoB & BtoIO & IOtoLS & LStoCP & CPtoC & CtoD & DtoE & $>$ E & Total \\
\hline 0 & 0 & 0 & 6.280 & 0 & 0 & 0 & 0 & 0 & 0 & 0 & 6.280 \\
\hline 1 & 62 & 32.139 & 6.262 & 18 & 0 & 0 & 0 & 0 & 0 & 0 & 6.280 \\
\hline 2 & 127 & 57.485 & 5.620 & 630 & 30 & 0 & 0 & 0 & 0 & 0 & 6.280 \\
\hline 3 & 165 & 64.825 & 5.268 & 842 & 159 & 11 & 0 & 0 & 0 & 0 & 6.280 \\
\hline 4 & 165 & 64.791 & 5.262 & 848 & 159 & 11 & 0 & 0 & 0 & 0 & 6.280 \\
\hline
\end{tabular}

Sendi plastis yang direncanakan supaya sesuai dengan mekanisme yang direncanakan yaitu strong column weak beam, dimana sendi plastis untuk struktur direncanakan dapat terjadi pada daerah ujung elemen balok, dan daerah ujung kolom.

Dari hasil analisis yang dilakukan dapat diketahui letak sendi plastis yang terjadi pada struktur SRPMK maupun SRPMM, pada step-step awal arah $X$ maupun arah $Y$ sudah terlihat adanya sendi 
plastis yang terbentuk di daerah balok. Pada step-step selanjutnya banyak elemen balok dan kolom yang sudah terbentuk sendi plastis. Hal tersebut menunjukkan bahwa struktur bangunan sudah sesuai dengan metode perencanaan kolom kuat balok lemah dan memenuhi kriteria desain pada struktur gedung.

\subsection{Kinerja Struktur}

Hubungan antara kurva kapasitas dengan performance point struktur SRPMK ditunjukkan oleh Gambar 5, dan Gambar 6, sedangkan untuk SRPMM ditunjukkan oleh Gambar 7, dan Gambah 8.

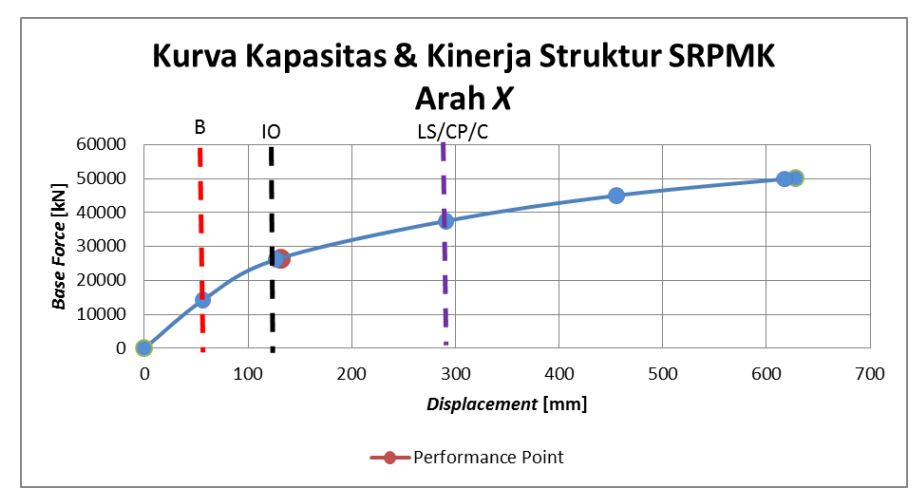

Gambar 5. Kurva kapasitas dan kinerja struktur SRPMK arah $X$



Gambar 6. Kurva kapasitas dan kinerja struktur SRPMK arah $Y$

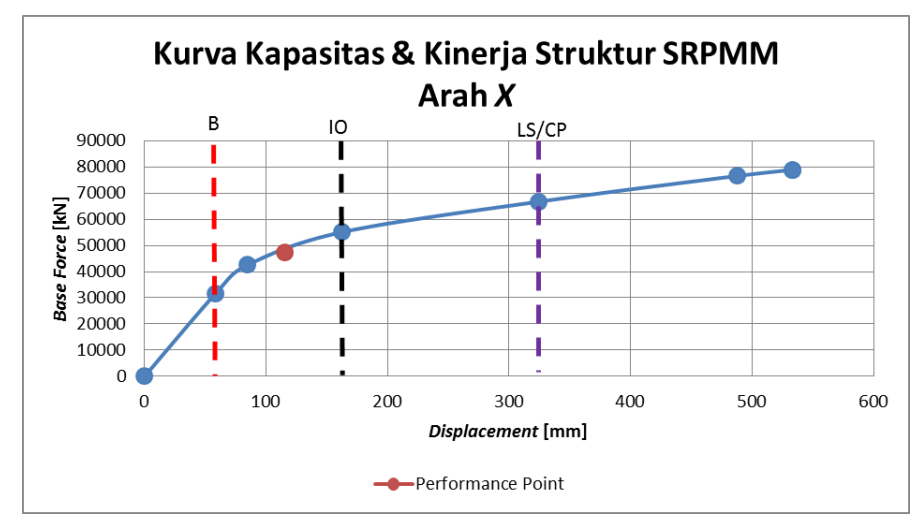

Gambar 7. Kurva kapasitas dan kinerja struktur SRPMM arah $X$ 


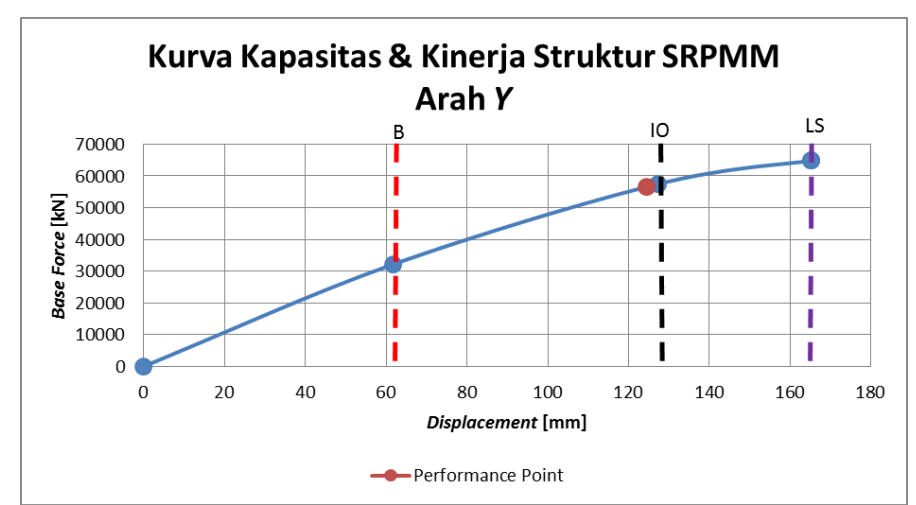

Gambar 8. Kurva kapasitas dan kinerja struktur SRPMM arah $Y$

Dari Gambar 6, Gambar 7, Gambar 8, dan Gambar 9 di atas didapatkan bahwa kinerja struktur pada saat kondisi Performance Point, kedua struktur berada pada level yang berbeda yaitu struktur ke1 (SRPMK) berada pada kinerja Immadiate Occupancy (IO) sampai dengan Life Safety (LS) yaitu kondisi dimana ketika terjadi gempa, struktur sudah terjadi kerusakan pada elemen struktural dan nonstruktural, dan bangunan bisa segera diperbaiki. Menurut FEMA 273 [5] bahwa struktur yang berada pada kinerja Immadiate Occupancy (IO) sampai dengan Life Safety (LS) akan menghabiskan biaya perbaikan sekitar 25\% sampai 50\% dari biaya pembangunan dan waktu perbaikannya sampai 30 hari. Sementara struktur ke-2 (SRPMM) berada pada kinerja B sampai Immadiate Occupancy (IO) yaitu kondisi dimana struktur beradapada kerusakan yang tidak parah sehingga apabila diperbaiki, perbaikannya tidak mengganggu fungsi dari bangunan.

Nilai daktilitas struktur ke-1 (SRPMK) baik pada arah $X$ maupun arah $Y$ pada kondisi runtuh adalah sudah mencapai daktilitas maksimum $(\mu=5,3)$, hal ini menunjukkan bahwa struktur sudah bersifat daktail penuh ketika sebelum struktur runtuh dan ini menujukkan struktur sudah memberikan kinerja yang baik. Sementara untuk struktur ke-2 (SRPMM) pada arah $X$ pada kondisi runtuh adalah sudah mencapai daktilitas maksimum $(\mu=5,3)$ dan pada arah $Y$ belum mencapai nilai daktilitas penuh. Apabila dibandingkan nilai daktilitas antara kedua struktur tersebut, struktur SRPMM baik untuk arah $X$ maupun untuk arah $Y$ memiliki daktilitas yang lebih kecil daripada struktur SRPMK, hal ini menunjukkan bahwa SRPMM lebih kaku dibandingkan struktur SRPMK. Selain itu struktur SRPMK dapat berdeformasi lebih besar saat menyerap energi gempa dibandingkan struktur SRPMM. Nilai daktilitas kedua struktur ditampilkan dalam Tabel 12 berikut:

Tabel 12. Nilai Daktilitas SRPMK dan SRPMM

\begin{tabular}{ccc}
\hline \multirow{2}{*}{ Tipe } & $\begin{array}{c}\text { Arah } \boldsymbol{X} \\
\boldsymbol{\mu}\end{array}$ & $\begin{array}{c}\text { Arah } \boldsymbol{Y} \\
\boldsymbol{\mu}\end{array}$ \\
\hline SRPMK & 11,11 & 5,54 \\
\hline SRPMM & 9,12 & 2,66 \\
\hline
\end{tabular}

Secara keseluruhan kedua struktur tersebut bisa dikatakan mampu memberikan kinerja cukup baik yang ditunjukkan oleh terpenuhinya persyaratan-persyaratan yang disyaratkan. Khususnya SRPMM yang dalam peruntukkannya untuk wilayah gempa sedang, namun dalam kasus ini dimodelkan pada wilayah gempa tinggi (KDS D) di Kota Yogyakarta. 


\section{KESIMPULAN}

1. Beban gempa yang terjadi pada struktur SRPMK lebih kecil daripada beban gempa yang terjadi pada struktur SRPMM, karena struktur SRPMK direncanakan dengan nilai faktor reduksi yang lebih besar $(R=8)$ daripada struktur SRPMM $(R=5)$.

2. Dalam desain struktur kasus ini, dimensi struktur SRPMK lebih kecil daripada dimensi SRPMM, hal ini dapat terjadi karena gaya dalam pada SRPMK lebih kecil daripada SRPMM yang disebabkan oleh nilai faktor reduksi yang lebih besar daripada SRPMM.

3. Simpangan yang terjadi pada struktur SRPMK lebih besar daripada struktur SRPMM, hal ini terjadi karena kekakuan pada struktur SRPMK lebih kecil daripada SRPMM yang terlihat dari dimensi SRPMK yang lebih kecil daripada SRPMM dan nilai perioda SRPMK lebih besar daripada SRPMM.

4. Besarnya beban geser yang dipikul oleh SRPMM lebih besar dibandingkan dengan SRPMK, hal ini merupakan keuntungan untuk struktur SRPMM karena dapat memikul beban geser yang lebih besar.

5. Perioda struktur yang terjadi pada struktur SRPMK lebih besar daripada struktur SRPMM, hal ini terjadi karena tingkat kekakuan struktur SRPMM lebih besar daripada struktur SRPMK.

6. Nilai daktilitas pada saat struktur sebelum runtuh: struktur SRPMK memiliki daktilitas yang lebih besar daripada SRPMM, hal ini terjadi karena SRPMM memiliki kekakuan yang lebih besar dari SRPMK.

7. Berdasarkan analisis non-linear pushover bahwa kedua struktur (SRPMK dan SRPMM) tersebut berada dalam level kinerja Immediate Occupancy (IO) sampai dengan Life Safe (LS) yaitu kondisi dimana suatu bangunan struktur setelah mengalami gempa, kekuatannya hampir sama dengan sebelum terjadinya gempa sehingga bangunan dapat kembali digunakan setelah terjadinya gempa.

8. Berdasarkan analisis yang dilakukan untuk struktur SRPMM pada wilayah gempa tinggi (Yogyakarta) menurut SNI 1726-2012 bahwa struktur mampu menunjukan performa yang baik, hal ini ditunjukan oleh terpenuhinya syarat-syarat yang telah disyaratkan dan kinerja struktur pada saat gempa terjadi berada pada fase Immadiate Occupancy (IO) sampai dengan Life Safe (LS).

\section{DAFTAR PUSTAKA}

[1] ATC-40. (1996). Seismic Evaluation and Retrofit of Concrete Building Volume 1. California: Applied Technology Council.

[2] Badan Standardisasi Nasional. (2002). SNI 1726-2002 tentang Standar Perencanaan Ketahanan Gempa untuk Struktur Bangunan Gedung. Jakarta: Badan Standardisasi Nasional.

[3] Badan Standardisasi Nasional. (2012). SNI 1726-2012 tentang Tata Cara Perencanaan Ketahanan Gempa untuk Struktur Bangunan Gedung dan Non Gedung. Jakarta: Badan Standardisasi Nasional.

[4] Badan Standardisasi Nasional. (2013). SNI 2847-2013 tentang Tata Cara Perhitungan Struktur Beton untuk Bangunan Gedung. Jakarta: Badan Standardisasi Nasional.

[5] FEMA-273. (1997). NEHRP Guidelines for the Seismic Rehabilitation of Building. Washington: FEMA.

[6] Hajati, N. L. (2013). Kajian Daktilitas Sistem Portal Berdinding Geser Terhadap Beban Lateral. Bandung: Jurusan Teknik Sipil Institut Teknologi Nasional.

[7] Kusnadi, Y. N. (2012). Evaluasi Seismik Struktur Gedung Asimetri dengan Pushover. Tugas Akhir. Bandung: Jurusan Teknik Sipil - Institut Teknologi Nasional.

[8] SAP2000. Tutorial SAP2000 versi 14.2.4. 